\title{
Beyond the Prevention - Overview of the AAPD History -
}

\author{
Dai-il Paik, Bo-Hyung Jin \\ Department of Preventive \& Social Dentistry, Seoul National University, Seoul, Korea
}

It has been passed more than two decades since AAPD $1^{\text {st }}$ meeting established in Fukuoka, Japan. The AAPD meeting has been devoted on the exchange and sharing of scientific information and collaboration of preventive dentistry among Asian countries. And also The International Journal of Preventive Dentistry has been published continuously.

Until nineties, the most of preventive works focused on the prevention of dental caries and periodontal diseases. In recent days, the focuses of preventive dentistry move to solve inequality of dental health, individualized dental health care plans by life cycle matching services and using genetic information to provide improving of quality of dental services as well as the prevention of dental diseases.

It is the time to review of the activities of AAPD meeting and planning the future role of Asian Preventive Dentistry.

Copyright (C) 2021. Korean Academy of Preventive Dentistry. All rights reserved.

This is an Open Access article distributed under the terms of the Creative Commons Attribution Non-Commercial License (http://creativecommons.org/licenses/ by-nc/4.0) which permits unrestricted non-commercial use, distribution, and reproduction in any medium, provided the original work is properly cited. 